\title{
Artur C. Danto, Czym jest sztuka, przeł. Anna Kunicka, Wydawnictwo Aletheia, Warszawa 2016, ss. 215
}

DOI: http://dx.doi.org/10.12775/RF.2018.023

Otóż sądzę, że jeśli pewna sztuka jest naśladownictwem, a inna nim nie jest, żaden $\mathrm{z}$ tych dwóch terminów nie spełnia definicji sztuki filozoficznie zrozumiałej ${ }^{1}$. Artur C. Danto

Zajmująca lektura rozprawy amerykańskiego historyka sztuki oraz filozofa Arthura Colemana Danto jest niewątpliwie kolejnym wnikliwym studium, poszerzającym perspektywę rozważań wokół rozmaitych problemów sztuki współczesnej. W krótkim wstępie autor pisze prowokująco, że: „Platon miał łatwe życie od V wieku p.n.e. do lat 1905-1907 i tzw. fowistów - Dzikich Zwierząt - oraz kubizmu"2. Jasne jest i takie być musi, że świat sztuki klasycznej dalece różni się od świata sztuki nowoczesnej, że nam współcześni z rzadka i chyba tylko z ciekawości zdają się zaglądać do jaskini Platona, nie wiedząc przy tym tak naprawdę, czego właściwie szukają i co powinni spostrzec. Tym trudniejsze zadanie przed sobą i czytelnikiem stawia autor, chcąc dociec tego, co uniwersalne w sztuce, bynajmniej w niektórych jej formach. Danto polemizuje z filozofami, którzy traktują pojęcie sztuki, jako „coś” niedefiniowalnego lub też uważaja, że termin ten, niczym wielki, otwarty pojemnik, jest w stanie pomieścić wszystko, co krytycy uznają za dzieło. W poszukiwaniu nadrzędnej cechy sztuki zostajemy wciągnięci w analityczny namysł nad tym, Czym jest sztuka. W perspektywie nakreślonej przez amerykańskiego myśliciela piękno nie jest czynnikiem definiującym. W czym zatem tkwi przysłowiowy haczyk?

Pierwszy z sześciu rozdziałów składających się na omawianą rozprawę na pierwszy rzut oka przypomina historyczny szkic, w którym autor wskazuje na podstawowe zmiany w sztuce, ale też w sposobie myślenia o działalności artystycznej przełomu dziewiętnastego i dwu-

1 A. C. Danto, „Czym jest sztuka”, Warszawa 2016, s. 11.

2 Ibidem, s. 12. 
dziestego wieku. Centralnymi postaciami tej historii w toku narracji stają się M. Duchamp i A. Warhol - artyści, którzy w sposób radykalny i bezkompromisowy odrzucili zastany porządek wiodących idei i wartości ówczesnego świata sztuki. Wzmiankowani artyści pośrednio zdjęli z wytworów artystycznych odium mimetycznego, tj. wiernego, możliwie realistycznego i "pięknego" odwzorowania otaczającej artystę rzeczywistości. Nie oznacza to jednak, że prace surrealistów, dadaistów, kubistów itd. nie miały nic wspólnego z rzeczywistością. Sęk w tym, że gra artysty i jego dzieła $\mathrm{z}$ odbiorcą toczyła się nie tylko $\mathrm{w}$ obszarze wyznaczonym przez przedmiot, lecz w większej mierze w wyobraźni odbiorcy, przypominając doświadczenie snu na jawie. Zdaniem Danto istotą sztuki współczesnej jest to, o czym pouczają prace Duchampa czy Warhola, że ucieleśniają one pewne znaczenia w przedmiotach, nierzadko codziennego użytku, takich jak choćby Warholowskie Brillo Box, na takiej zasadzie, na jakiej: „Sny składają się z pozorów, ale muszą to być pozory rzeczy ze świata" ${ }^{\prime}$. W konsekwencji komercyjne pudełka marki Brillo - formalnie - nie różnią się w żaden szczególny sposób od Warholowskich Brillo Box. To, co je od siebie odróżnia, to znaczenie, jakie przypisał im amerykański artysta. Warhol wprowadził do świata sztuki "wysokiej" produkty charakterystyczne dla kultury popularnej zaraz po tym, jak Duchamp z pisuaru uczynił dzieło sztuki typu ready mades.

Wplątanie nam współczesnych filozofów, krytyków, kuratorów i konserwatorów w „zasieki” klasycznych kategorii estetycznych może doprowadzić - o czym przekonuje Danto w drugim rozdziale rozprawy - do zatarcia ucieleśnionego w dziele znaczenia. Nie od dziś bowiem wiadomo, że praca konserwatorów jest niezwykle wymagająca. Renowacja fresków sykstyńskich Michała Anioła wywołała szeroką dyskusję o tym, czy to, co uznano za brud (okopcenie przez świece i kadzidła), nie było czasem wartościową częścią nietuzinkowego dzieła sztuki? Czy przeciwnie, zbliżono się do oryginału, oddając barwy takimi, jakimi widział je, malując, Michał Anioł? Zakładając, pisze Danto: „[...] że to, co zmyto, stanowiło metaforyczny cień kondycji ludzkiej, jaką symbolizowała Platońska jaskinia, [to - J. M.] intensyfikacja barw odbyła się strasznym kosztem utraconego już znaczenia?" ${ }^{4}$. Autor omawianej rozprawy zdaje się podzielać przekonanie tych krytyków mówiące, że zdarłszy historycznie narastające warstwy, niechlubnie pozbyto się tej intencyjnie pomieszczonej przez samego artystę; po pierwsze, w dłuższej perspektywie czasu tego, co znaczące, po drugie tego, co bezwzględnie istotne dla monochromatycznego wyrazu pracy w warstwie malarskiej gry światła i cienia. Gianluigi Calalucci odpowiedzialny za renowację fresków zdecydował się na to, aby oddać geniusz Michała Anioła

3 Ibidem, s. 74.

4 Ibidem, s. 83. 
w sposób możliwie „obiektywny”, gdyż twierdził, że: „Jeśli będziemy próbowali interpretować dzieło sztuki, skończymy na narzucaniu warunków procesu czyszczenia" ${ }^{5}$. Calalucci, wierny swym poglądom, zdaniem amerykańskiego filozofa sztuki, zupełnie zignorował fakt doboru przez Michała Anioła techniki al secco, która nie czyniła z fresku, a co stało się udziałem Calalucciego, dzieła: „,...] jak gdyby Michał Anioł był w jakimś sensie impresjonistą..." ${ }^{\prime}$. Inaczej mówiąc, włoski konserwator zabytków stał się zakładnikiem interpretacji fresku dokonanej przez jej autora. Z renowacji dzieła na drodze metody „kolejnych pociągnięć pędzla", tj. metody pozbawionej interpretacji artystycznej, a dążącej do ideału obiektywnego oddania, nie wynika nic ponad - w tym przypadku przerysowany, wciąż genialny, ale tylko obraz na sklepieniu, fizyczny przedmiot, obiekt. Trudno z powyższym się nie zgodzić, $\mathrm{t} n$. z tym, że fresk jest czymś materialnym, ale: „,[...] dzieło sztuki jest wyrażonym znaczeniem, a znaczenie misternie wiąże się z obiektem materialnym jak dusza z ciałem. Michał Anioł - przekonuje Danto - stworzył zarówno świat, jak i obiekt, trzeba spróbować wejść do świata w celu przekonania się, jakie części obiektów fizycznych są relewantne"

Wynika stąd jasno, że znaczenie w sztuce potrzebuje medium. Dla Danto, wybitnego znawcy filozofii kontynentalnej, posiadanie ciała w rozmaitych kontekstach, okaże się kluczem do nadawania każdemu doświadczeniu pewnej formy. Dla teologii cielesność Boga w osobie Chrystusa nie wzbudza większych kontrowersji. W sztuce za czasów Kartezjusza liczne przedstawienia, do których odwołuje się Danto, ukazują świętą rodzinę, jako rodzinę właśnie, tj. w sposób czytelny dla odbiorcy, który rzecz jasna również posiada ciało, a zatem sposób nadawania i odczytywania a priori znajomych form, również tych przetransponowanych przez artystę, np. na płótna malowanych przez siebie obrazów. Kartezjusz, zdaniem amerykańskiego myśliciela, nie tyle zanegował oczywisty fakt posiadania ciała, nawet jeśli miałoby ono być swego rodzaju „maszyną”, ile przeciwnie: odróżnił je od Cogito na drodze analizy logicznej. Z faktu, że ciało jest „więzieniem dla duszy”, nie wynika, iż umysł nie jest ucieleśniony. To, jak rozumiemy ciało w filozofii, w sztuce, religiach, ale też na gruncie psychologii potoczne ${ }^{8}$, umożliwia nam wczucie się w postać greckiej tragedii, medium ciała daje nam szanse skonfrontowania się (nierzadko dosłownie) z dziełem sztuki typu performance.

Jeśli ciało jest bliskie sztuce, jak twierdzi Danto, a z czym trudno się nie zgodzić, to niewątpliwie sposób, w jaki widzi ludzkie oko, jest bliski

\footnotetext{
5 Ibidem, s. 87.

6 Ibidem, s. 88.

7 Ibidem, s. 95.

8 Zob. ibidem, s. 135.
} 
temu, jak „widzi” aparat fotograficzny. Bliskie, ale z nim nietożsame, co otworzyło szerokie perspektywy wszystkim tym artystom, którzy zdecydowali się porzucić klasyczną perspektywę malarską oraz precyzyjna, niemal nadludzką możliwość widzenia po-przez aparat fotograficzny. Bo, o ile ten ukazał niedociągnięcia postrzegania "prawdy wizualnej” nieuzbrojonym okiem, o tyle za sprawą wszelkiego rodzaju skrótów perspektywicznych, wypaczeń, nieśmiało zwykł, jeśli można tak powiedzieć, zapraszać co bardziej odważnych artystów do współtworzenia nowoczesnej moderny, dla której aparat fotograficzny był maszyną godną uwagi, tak jak były nimi statki, samoloty, auta, a wszystko w ruchu, lecz nierzadko na uwięzi stopklatki kamery. I tak z jednej strony aparat fotograficzny zdjął z artystów odium realistycznego, mimetycznego oddawania fragmentów rzeczywistości, wypełniając to zadanie należycie, z drugiej zdehumanizował w swym automatyzmie twórczość artystyczną dalece podważając autorytet genialnego artysty oraz oryginalnego dzieła sztuki, co dobitnie wydobyli na światło dzienne choćby Warhol i Duchamp, a gdzie ten drugi, jak pisze autor: „[...] ponownie wynalazł pojęcie sztuki, sprawiając, że zarówno ręka i oko, jak i estetyka utraciły znaczenie dla definicji sztuki" ${ }^{\prime}$. Trudno powiedzieć, jak wielki wpływ miało wynalezienie fotografii dla przebiegu tego zuchwałego odwrotu artystów od klasycznych wartości estetycznych. Dość swobodnie snute rozważania amerykańskiego filozofa nie prowadzą moim zdaniem do jednoznacznych rozstrzygnięć.

Niebagatelne zasługi dla organicznego, całościowego oraz analitycznego podejścia do zagadnień estetycznych, ich umówienia i skorelowania z innymi władzami ludzkiego umysłu zawdzięczamy oczywiście Immanuelowi Kantowi. Filozofowi z Królewca poświęca Danto piąty, przedostatni rozdział pracy. Cóż może w filozofii Kanta okazać się ideą nośną dla pewnego modus operandi sztuki modernizmu oraz postmodernizmu? Amerykański filozof nawiązuje do koncepcji piękna wolnego Kanta oraz pojęcia ducha. Tym, co niezwykle ważne w recepcji każdego dzieła sztuki, jak i dla wszelkiego rodzaju twórczości artystycznej, niezależnie od okresu historycznego, będzie niezbywalny, również dla Kanta, związek między tym, co duchowe, z tym, co podmiotowe, a związane z poznaniem w ogóle, bo jak sam pisze: „W ten sposób sztuka w jego ujęciu, [tj. Kanta - J. M.] wykorzystuje doświadczenie, żeby zabrać nas poza jego granice"10 ${ }^{10}$ Z zaskakującą łatwością amerykański filozof, powołując się m.in. na twórczość Kirka Varnedoe, przekonuje, że: „[...] drugi pogląd Kanta na sztukę głosi, że polega ona na nadawaniu znaczeń, co zakłada ogólnoludzką dyspozycję, nie tylko do widzenia rzeczy, ale też poznajdywania znaczeń w tym, co widzimy, nawet jeśli coś rozumiemy

9 Ibidem, s. 155.

10 Ibidem, s. 169. 
źle..."11. W istocie trudno o jedno, poprawne odczytanie idei wyrażonej przez artystę w nowoczesnym dziele sztuki. Otwiera to drzwi dla niezbywalnej w całym tym obustronnym procesie - szerokiej dziedziny oraz umiejętności interpretacji znaczeń, które mieści w sobie - ucieleśnia - dany wytwór. Mało rozsądna moim zdaniem jest tego rodzaju spekulacja, a co by było, gdyby Kant żył w XXI wieku? Zabieg ten nie ułatwia, ani odczytania daleko idącego skrótu poczynionego przez autora względem podstawowych idei transcendentalnej filozofii Kanta, ani też odczytania rozprawy Danto. Chęć ukazania wycinka twórczości filozofa z Królewca jako zdatnej w pewnej mierze do oddania uniwersalnej prawdy sztuki, również tej współczesnej, ma swoje uzasadnienie, gdyż sam Kant stara się połączyć to, co a priori podmiotowe i niezbywalne w poznaniu, z tym, co sztuczne, a co nazywamy sztuka, a w zasadzie doświadczeniem estetycznym?

Rozprawę Czym jest sztuka wieńczy rozdział zatytułowany Przyszłość estetyki. Danto pisze, że: „Przez estetykę będę rozumiał sposób, w jaki rzeczy się pokazuja, wraz z powodami przedkładania jednego sposobu pokazywania się nad inny"12. Duchamp i Warhol dobitnie pokazali, że estetyka nie jest potrzebna do tworzenia dzieł sztuki, tak jak ją rozumiał choćby Kant. Z drugiej strony trudno zbagatelizować działania obu artystów. Dzięki ich twórczości jasne się stało, że estetyka nie jest częścią definicji sztuki współczesnej, tak jak dzieła nie muszą być np. piękne, ale też nie oznacza to, iż estetyka jako taka nie była nigdy częścią sztuki. Autor omawianej rozprawy lawiruje między zasadnością rozważań estetycznych oraz ich ekspozycją $\mathrm{w}$ ramach filozofii, ale też $\mathrm{w}$ świecie sztuki, podkreśla przy tym, że nie pełni ona - dla większości artystów i teoretyków - centralnej funkcji. Danto jako krytyk z ogromnym doświadczeniem podkreśla, że duża część sztuki współczesnej wcale nie grzeszy estetyką, ale $\mathrm{w}$ zamian cieszy się siłą znaczenia i możliwością prawdy, a także zależy od interpretacji, która wprowadza ją do gry"13. Dziełem sztuki jest więc „przedmiot”, który ucieleśnia znaczenie, umożliwia interpretację (również wolną od pojęć estetyki), mając na względzie pewną prawdę, która nie musi w ścisłym tego słowa znaczeniu wiązać się wprost z danym wytworem. Musi istnieć związek między czystymi formami naoczności, o których pisał Kant, z całym imaginarium sztuki w ogóle, zdaje się przekonywać Danto.

Niewątpliwie recenzowana rozprawa jest wymagającą lektura, choćby z racji luźnego, tj. eseistycznego sposobu pisania, pełnego odniesień do rozmaitych koncepcji filozoficznych oraz pokaźnej liczby dzieł sztuki. Danto, jeśli można tak powiedzieć, prześlizguje się między nierzadko

11 Ibidem, s. 175.

12 Ibidem, s. 184.

13 Ibidem, s. 208. 
sprzecznymi teoriami filozoficznymi oraz artystycznymi, nie poświęcając wiele miejsca na ich precyzyjne objaśnienie. Owszem, nie jest to praca historyczna, lecz jej poprawne odczytanie wymaga od czytelnika znajomości wcześniejszych prac autora oraz ogólnej wiedzy filozoficznej, w szczególności z zakresu estetyki.

Jakub Maciejewski

Uniwersytet Mikołaja Kopernika, Torun e-mail: jakub_m@doktorant.umk.pl 